\title{
Production and characterization of xylanase from pomegranate peel by Chaetomium globosum and its application on bean under greenhouse condition
}

\author{
Sherien M. M. Atalla ${ }^{1 *}$ and Nadia G. El Gamal²
}

\begin{abstract}
Background and objective: The main objective of the present study was production of xylanase from different agricultural wastes using Chaetomium globosum on pomegranate waste, isolation of fungi associated with some legumes seeds, and studied the effect of safe product which obtained from xylanse under laboratory and greenhouse conditions on bean seeds.

Results and discussion: Different agricultural wastes were tested for xylanase production by Ch. globosum; from them, pomegranate peel was most effective at concentration $40 \mathrm{~g} / \mathrm{l}$ using 2 disks $6 \mathrm{~mm}$ in diameter after 7-day incubation period produces $1398.34 \mathrm{U} / \mathrm{ml}$. Addition of calcium chloride increases xylanase activity to $1469.40 \mathrm{U} / \mathrm{ml}$. The crude xylanase activity was active after 20 min of starting of reaction at $6.6 \mathrm{pH}$, and $40{ }^{\circ} \mathrm{C}$ of the reaction mixture produces $1587.27 \mathrm{U} / \mathrm{ml}$. Xylanse is still active at $40{ }^{\circ} \mathrm{C}$ for $30 \mathrm{~min}$. Seeds of some legumes were examined for seed borne mycoflora by the agar plate method. The most common fungi were Fusarium solani, Rhizoctonia solani, and Macrophomina phaseolina.

Testing of crude xylanase as biocide was more effective in reduction of linear growth of some pathogenic fungi also applied the biocide as seed treatment of bean. Seed coating with biocide gave significant protection to emerge bean seeds against invasion of pathogenic fungi at the pre-emergence stage. Seed coating recorded more than $50 \%$ protection compared with the untreated control.
\end{abstract}

Conclusion: Production of xylanase from pomegranate peel wastes using Chaetomium globosum under optimum conditions. Testing crude xylanase after optimization as an effective biocide.

Keywords: Xylanase, Chaetomium globosum, Pomegranate peel, Soil born fungi

\section{Introduction}

Xylan (E.C.2.8.1.8) is one of the major hemicellulose components of plant cell wall consist of backbone of $\beta$-14linked xylopyranose residues with branches containing arabino-furanosyl, acetyl, and glucuronosyl residues. In

\footnotetext{
*Correspondence: atallams@yahoo.com

'Chemistry of Natural and Microbial Products Department, Pharmaceutical and Drug Industries Research Division, National Research Centre (NRC), Dokki, Giza 12622, Egypt

Full list of author information is available at the end of the article
}

the plant cell wall, hemicellulose is highly branched and tightly associated with other biopolymers (Jae et al. 2009).

Xylanase from different microorganisms such as fungi, bacteria, marine algae, and yeast gained interest due to their potential applications in many industrial processes as well as using agro industrial residues are good source of nutrition for the growth of the microorganisms and cheap natural carbon sources. The production of the enzyme xylanase can be used for industrial applications, commercial purposes including chlorine free bleaching of the wood pulp prior to papermaking, food additives in 
poultry and in wheat flour for increasing the quality of baked products and improving the handling of dough, and for the extraction of coffee, extraction of starch and plant oils and considered important as they contain large amount hemicelluloses and serve as inducers for the production of enzymes such as xylanases which led to the development of bioprocesses for the effective use of agro wastes (Shabeena et al. 2017; Nitin et al. 2017; ElMohamedy et al. 2018 ;Atalla et al. 2019).

Many fungal pathogens, some of which are seed transmitted, often reduce the germination ability or kill the infected plants or substantially reduce the productive. Some of these fungi produce aflatoxins which damage the liver and induce carcinogenic, mutagenic. Thus, control of seed borne fungi is extremely important, and the damaging effects can be relieved through integrated approaches (Agarwal et al. 2011).

The seeds are locally produced or imported and stored by the farmers under poor quarantine. Therefore, seed contamination can occur by seed borne fungi which adversely affect the production and productivity of these crops.

Seeds play a vital role in the production of healthy crops. Healthy seed is the foundation of healthy plant, a necessary condition for good yields (Diaz et al. 1998). Hence, this study has been undertaken to investigate the percentage incidence of seed borne fungi associated with some varieties of legumes.

During the industrial processing of pomegranate, large volume of wastes is produced, which have a wide range of nutritional values. Therefore, in the recent years, scientists have focused on the industrial byproducts of pomegranate that have a high potential of antioxidant and antifungal properties (Dahham et al. 2010).

The main objective of the present study was production of xylanase from different agricultural wastes using Chaetomium globosum on pomegranate waste, isolation of fungi associated with some legumes seeds, and studied the effect of safe product which obtained from xylanse under laboratory and greenhouse conditions on bean seeds.

\section{Materials and methods Microorganisms}

Chatemouim globosum is a local fungal strain isolated from Egyptian soil. It was identified in Plant Pathology Department of National Research Centre, Giza, Egypt, according to Barnett and Hunter (1972) and Nelson et al. (1983). The strain was kept on a potato dextrose agar medium and stored at $4{ }^{\circ} \mathrm{C}$.

Three fungal pathogens $F$. solani, M. phaseolina, and $R$. solani were selected from preliminary test of isolated from legume seeds The fungi in pure culture were identified after pathogenicity test according to the keys given by Barnett and Hunter (1972) and Nelson et al. (1983).

Common legume seed samples were collected in polythene envelopes from different market from Egypt and taken to the laboratory for isolation of fungal pathogens.

\section{Substrates}

Different agricultural residues (banana peel, pea peel sawdust, peanuts, pomegranate peel (Pp), potato peel, wheat straw, sugar cane bagasse, soy bean) were used as sole carbon source and tested for xylanase production. All wastes were washed, dried at $70{ }^{\circ} \mathrm{C}$ in oven, and cut into small pieces $(1 \mathrm{~cm} \times 1 \mathrm{~cm})$ before used.

\section{Fermentation condition}

The ability of the microorganism for xylanase production was examined in medium containing $(\mathrm{g} / \mathrm{l}) \mathrm{NaNO}_{3}$ 2.0, $\mathrm{K}_{2} \mathrm{HPO}_{4} 0.5, \mathrm{KCl} 0.5, \mathrm{MgSO}_{4} 0.7, \mathrm{H}_{2} \mathrm{O} 0.5$, and different agricultural wastes (20.0). Erlenmeyer flasks 250 $\mathrm{ml}$ each containing $50 \mathrm{ml}$ fermentation medium were inoculated with two disks $6 \mathrm{~mm}$ in diameter of the selected microorganism and incubated at $28 \pm 30{ }^{\circ} \mathrm{C}$ for 7 days in incubator shaker at $200 \mathrm{rpm}$.

\section{Xylanase assay \\ Determination of enzyme activity was carried out ac- cording to the method of Monreal and Reese (1969). \\ One milliliter of $1 \%$ birch wood xylan (Sigma) in acet- ate buffer ( $\mathrm{pH} 4.6$ ) in test tubes was added to $1 \mathrm{ml}$ of the culture filtrate and mixed by shaking. The mixture was incubated in a water bath at $50{ }^{\circ} \mathrm{C}$ for $30 \mathrm{~min}$ and then cooled and centrifuged before assaying. The amount of reducing sugar was determined with $1 \mathrm{ml}$ of 3,5-dinitro- salicylic acid (DNS). One unit of enzyme activity was taken of the catalyst converts one $\mu \mathrm{mol}$ of substrate in 1 min under specific condition.}

\section{Effect of different agricultural residue}

In order to induce xylanase synthesis from microbial sources from cheap and most economic carbon source, $20 \mathrm{~g}$ of different agricultural residues (banana, pea peal, sawdust, peanuts, pomegranate peel, potato peel wheat straw, sugar cane baggase, and soy bean) in comparison with control was added to fermentation medium.

\section{Optimization of culture conditions}

Optimization conditions were carried out depends on addition of different $(\mathrm{Pp})$ concentrations ranging from 5 to $120 \mathrm{~g} / \mathrm{l}$. Different inoculum size 2 disks $(2,4,6$, and 8 $\mathrm{mm})$ in diameter, different incubation period $(5,7$, and 10) days, and addition of different salts (sodium bicarbonate, calcium carbonate, potassium sorbate, calcium 
chloride) were obtained from Sigma Aldrich Spruce Street, St. Louis, USA.

\section{Characterization of crude xylanase activity} Optimization of crude xylanase activity was carried out using crude filtrate of C. globosum. Effect of different reaction time was carried out in the reaction mixture ranging from 10 to $60 \mathrm{~min}$, followed by changing $\mathrm{pH}$ values from 3.6 to 7.0. The temperature of the reaction was analyzed by incubated reaction for $10-60{ }^{\circ} \mathrm{C}$.

\section{Thermal stability}

Thermal stability was analyzed by incubating the crude filtrate at different temperature with different time intervals, and then, residual activity was measured.

\section{Collection of the seed samples}

Twenty seed samples are from 5 leguminous crop, namely, Pisum sativm (pea), Vicia faba (faba bean), Cicer arietinum (chickpea), Phaseolus vulgaris (white bean), and Lens culinaris (lentil).

\section{Seed Borne fungi analysis}

Detection of seed borne fungi from selected legume seeds was done by agar plate method as recommended by ISTA (1976).

\section{Frequency of occurrence of isolated fungi}

Frequency of fungal isolates was calculated according to Al-Abdalall (2008).

\footnotetext{
$\%$ Frequency $=$ total number of fungal isolates $/$ crop $/$ number of fungal isolates $\times 100$.
}

\section{Evaluation of the efficacies of crude xylanase produced against different fungal isolates}

Agar well diffusion method crude xylanase from C. globosum was screened for antifungal activity using sterile cork borer of size $6.0 \mathrm{~mm}$ in diameter according to Bobbarala et al. (2009). Five hundred microliters of crude xylanase solution homogenized added to $0.02 \mathrm{ml}$ of inoculums filled in deep blocks. Incubation period of 48-72 $\mathrm{h}$ at $25{ }^{\circ} \mathrm{C}$ was maintained for antifungal activity. Radial inhibition was calculated when growth of mycelia in the control plate reached the edge of the petri dish. The toxicity of the extracts to growth of fungi was calculated by using the formula percentage (\%) inhibition $=\mathrm{dc}-\mathrm{dt} / \mathrm{dc}$ $\times 100$, where $\mathrm{dc}=$ average increase in mycelial growth in control and $\mathrm{dt}=$ average increase in mycelial growth in treatment (Singh and Tripathi 1999)

\section{Greenhouse experiment}

Three fungal pathogens $F$. solani, M. phaseolina, and $R$. solani were selected from preliminary test of isolated from legume seeds which showed the highly percentage of occurrence and evaluate the biocide prepare from $C$. globosum grown on Pp waste under greenhouse conditions for bean seed $P$. vulgaris. Sandy clay soil was transferred in pots. Inoculum from each cultures was colonized separately and infested at the rate of $3 \mathrm{~g} / 100 \mathrm{~g}$ soil. The disinfected bean seeds were coated with a biocide at the rate of $4 \mathrm{ml} / \mathrm{kg}$ seeds. Seed dressing was carried out by applying the biocide to the gum moistened seeds in polyethylene bags and shaking well to ensure even distribution of the added materials then left to air dried. Five replicates/treatments, pathogen free seeds were surface sterilized and planted ( 5 seeds/pot) in inoculated and non-inoculated soils. All pots maintained in greenhouse under natural condition, for 15 days after sowing. Disease ratios were determined by recording the number of non-emerged seeds (pre-emergence damping-off) while post-emergence damping off was recording from 30 to 45 days after sowing. The equations described by Khalifa (1987) were as follows:

$$
\begin{aligned}
& \text { Pre-emergence }(\%) \text { damping off } \\
& =\text { no.of non-emerged seeds/no.of sown seeds } \\
& \quad \times 100
\end{aligned}
$$

\section{Statistical analysis}

Tukey test for multiple comparisons among means was utilized (Neler et al. 1985).

\section{Results}

\section{Production of xylanase from different agricultural} residues

The results in Fig. 1 showed that pomegranate peel $(\mathrm{Pp})$ produces maximum xylanase activity $1046.20 \mathrm{U} / \mathrm{ml}$, followed by wheat bran produces $663.87 \mathrm{U} / \mathrm{ml}$, then pea peel produces $618.13 \mathrm{U} / \mathrm{ml}$; other wastes showed moderate to low activities in comparison with control.

\section{Different pomegranate peels $(\mathrm{Pp})$ concentrations}

The results in Fig. 2 showed that xylanase activity increases by increasing Pp concentrations till reached 40 $\mathrm{g} / \mathrm{l}$ which was the most suitable concentration producing $1398.34 \mathrm{U} / \mathrm{ml}$ followed by $50 \mathrm{~g} / \mathrm{l}$ producing $1286.01 \mathrm{U} / \mathrm{ml}$ then $60 \mathrm{~g} / \mathrm{l}$ producing $1280.01 \mathrm{U} / \mathrm{ml}$.

\section{Effect of different inoculum size}

The results in Fig. 3 showed that activity on the xylanase increases till reaching $1398.34 \mathrm{U} / \mathrm{ml}$ after inoculation with 2 disks $6 \mathrm{~mm}$ in diameter; then, the activity decreased. 


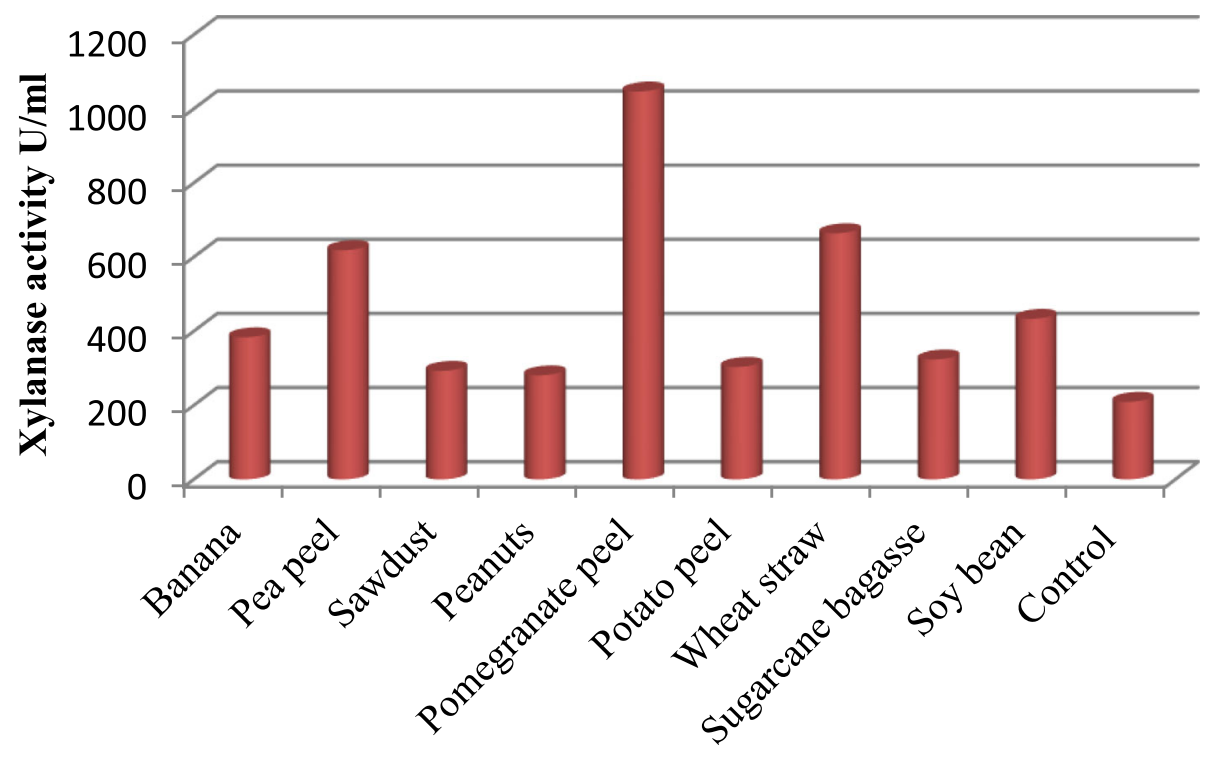

Different agricultural wastes (g/l)

Fig. 1 Effect of different agricultural wastes on xylanase production by C. globosum

\section{Different incubation periods (days)}

The results recorded in Fig. 4 showed that 7-day incubation period was the most suitable for xylanase production producing $1401.13 \mathrm{U} / \mathrm{ml}$ followed by 5 -day incubation period producing $1398.34 \mathrm{U} / \mathrm{ml}$.

\section{Addition of different salts}

The data in Fig. 5 showed that the addition of calcium chloride increases xylanase activity producing $1469.40 \mathrm{U} / \mathrm{ml}$, followed by potassium sorbate producing $975.60 \mathrm{U} / \mathrm{ml}$ while addition of other salts reduces xylanase activity.

\section{Characterization of crude xylanase activity Effect of different reaction time}

The results in Fig. 6 revealed that time of reaction increases till reached $20 \mathrm{~min}$ after the start of the reaction produces maximum xylanase activity of $1473.39 \mathrm{U} / \mathrm{ml}$; then, activity of reaction begins to decrease.

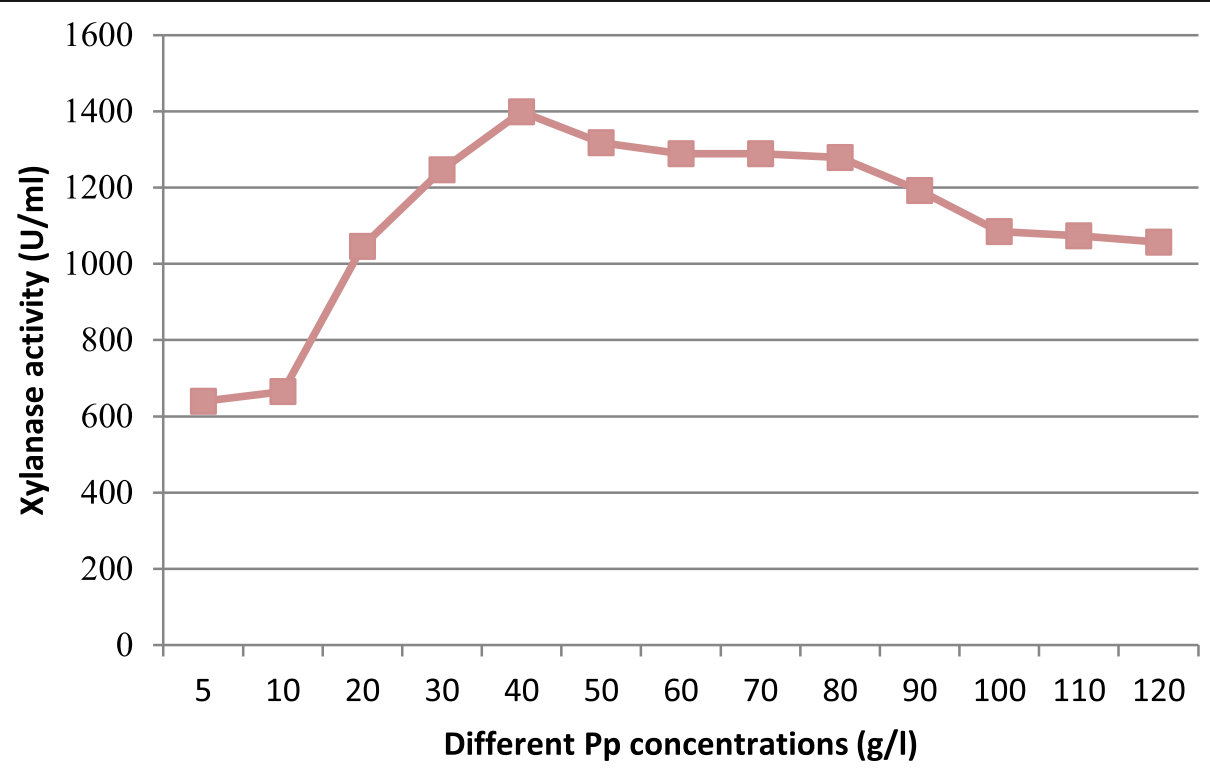

Fig. 2 Effect of different concentrations of pomegranate peel on xylanase activity 


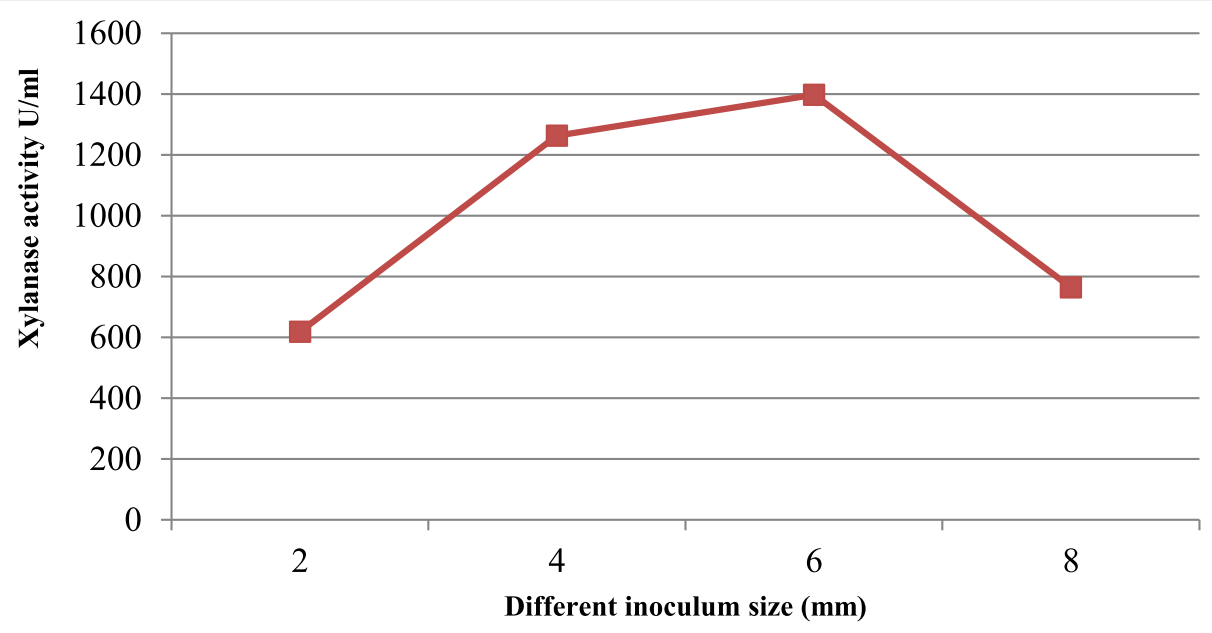

Fig. 3 Effect of different inoculum size on xylanase production

\section{Different $\mathrm{pH}$ values}

Different $\mathrm{pH}$ values were analyzed using crude filtrate of xylanase after 20 min of reaction. The results in Fig. 7 presented that xylanase activity increased with increasing $\mathrm{pH}$ values till reaching $\mathrm{pH} 6.6$ producing $1708.74 \mathrm{U} / \mathrm{ml}$ followed by $\mathrm{pH} 6.0$ producing $1726.05 \mathrm{U} / \mathrm{ml}$; then, the activity decreased. This means that addition of pomegranate peel as a carbon source in the fermentation medium increases the ability of the crude filtrate to resist increase in different $\mathrm{pH}$ values.

\section{Different temperature of the reaction mixture}

The results in Fig. 8 showed that xylanase activity increases till reached $40{ }^{\circ} \mathrm{C}$ which was the most promising temperature for xylanase activity producing $1587.27 \mathrm{U} /$ $\mathrm{ml}$ followed by $30{ }^{\circ} \mathrm{C}$ producing $1473.39 \mathrm{U} / \mathrm{ml}$ then 20 ${ }^{\circ} \mathrm{C}$ producing $1405.27 \mathrm{U} / \mathrm{ml}$.

\section{Thermal stability}

The data present in Fig. 9 showed that increasing the exposure time of crude xylanase up to $40{ }^{\circ} \mathrm{C}$ for $30 \mathrm{~min}$ decreases xylanase activity up to $45 \%$, while at a $60{ }^{\circ} \mathrm{C}$ enzyme lost $85 \%$ of its activity. Thermal stability is an interesting enzymes property due to the great industrial importance. Crude xylanase from $P$. sclerotiorum was stable at $50{ }^{\circ} \mathrm{C}$; increase in thermal stability would be interesting and could be achieved with directed site mutagenesis.

\section{Seed borne fungi analysis:}

The fungi which appeared on seed were isolated in pure culture for identification and for further study. In agar plate method, pre-sterilized petri plates were poured with $15 \mathrm{ml}$ of autoclaved (PDA). On cooling the medium, three replicates of ten seeds/plate of the sample were equidistantly placed aseptically. The plates were

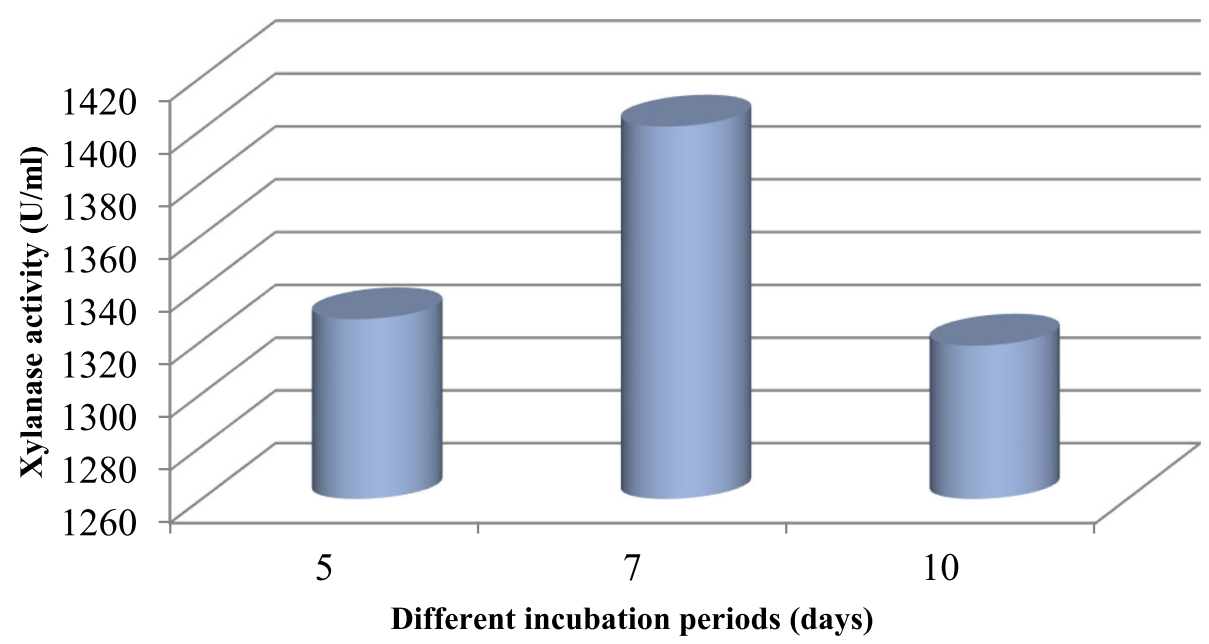

Fig. 4 Effect of different incubation periods (days) on xylanase production 


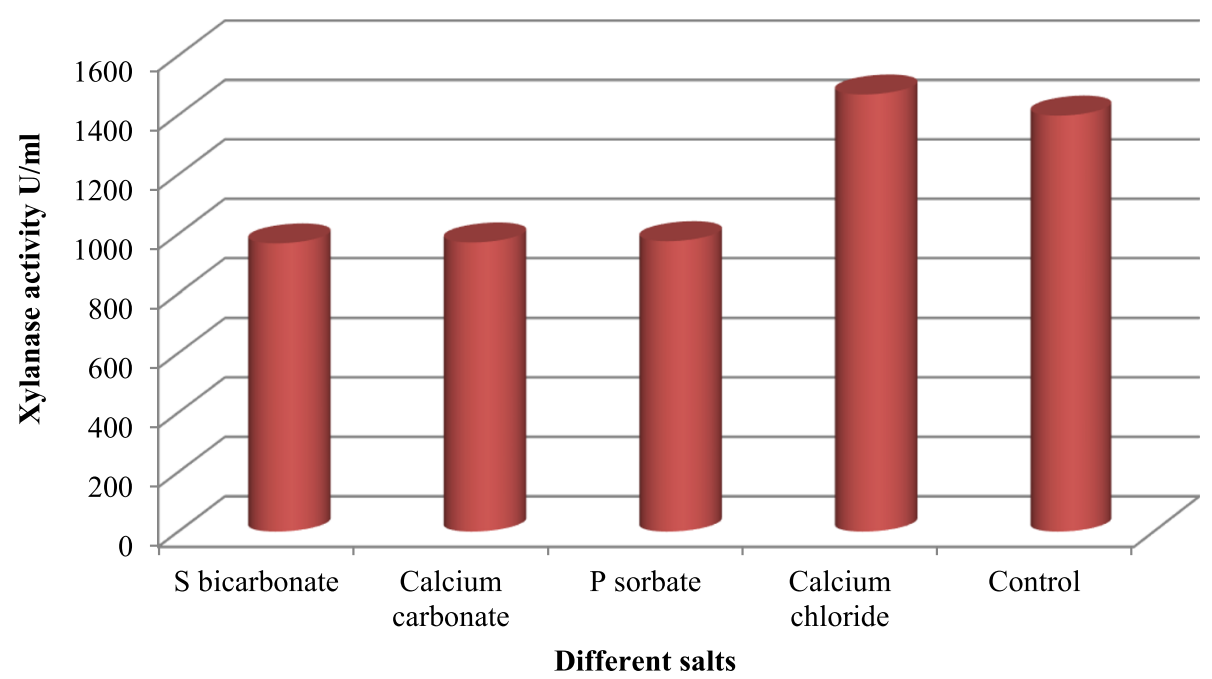

Fig. 5 Effect of different addition of salts on xylanase production

incubated at $25 \pm 2{ }^{\circ} \mathrm{C}$ under diurnal conditions. On seventh day of incubation, seeds were first examined under stereoscopic microscope for determining the various fungal growths. Seed borne fungal pathogens were isolated from seeds on potato dextrose agar (PDA) using agar plate method as described by Anonymous (1993). The isolated fungi were identified using cultural appearance and microscopic characteristics (Ogbulie et al. 2001).

\section{Frequency of fungal isolates}

Many fungal species were isolated and identified from the collected seed samples using the agar plate method. Fungi were frequently isolated from all seeds (Table 1 ); $R$. solani is the most frequently isolate (27.3 to $43.5 \%$ in Faba bean) from all samples and also F. solani (26.0 to $33.3 \%$ ) and M. phaseolina (32.0\%) in white bean, followed by $A$. niger (8.0 to 17.4\%) and P. spp. (13 to 13.3\%). Differences in isolation and frequency may be due to variation in the moisture content of seeds, varietal differences, and seed susceptibility to infection besides specific environmental conditions in each seed store.

A seed borne pathogen presents externally, internally, or associated with the seed as contaminant may cause seed abortion, seed rot, seed necrosis, reduction, or elimination of germination capacity as well as seedling damage resulting in the development of disease at later stages of plant growth by systemic or local infection.

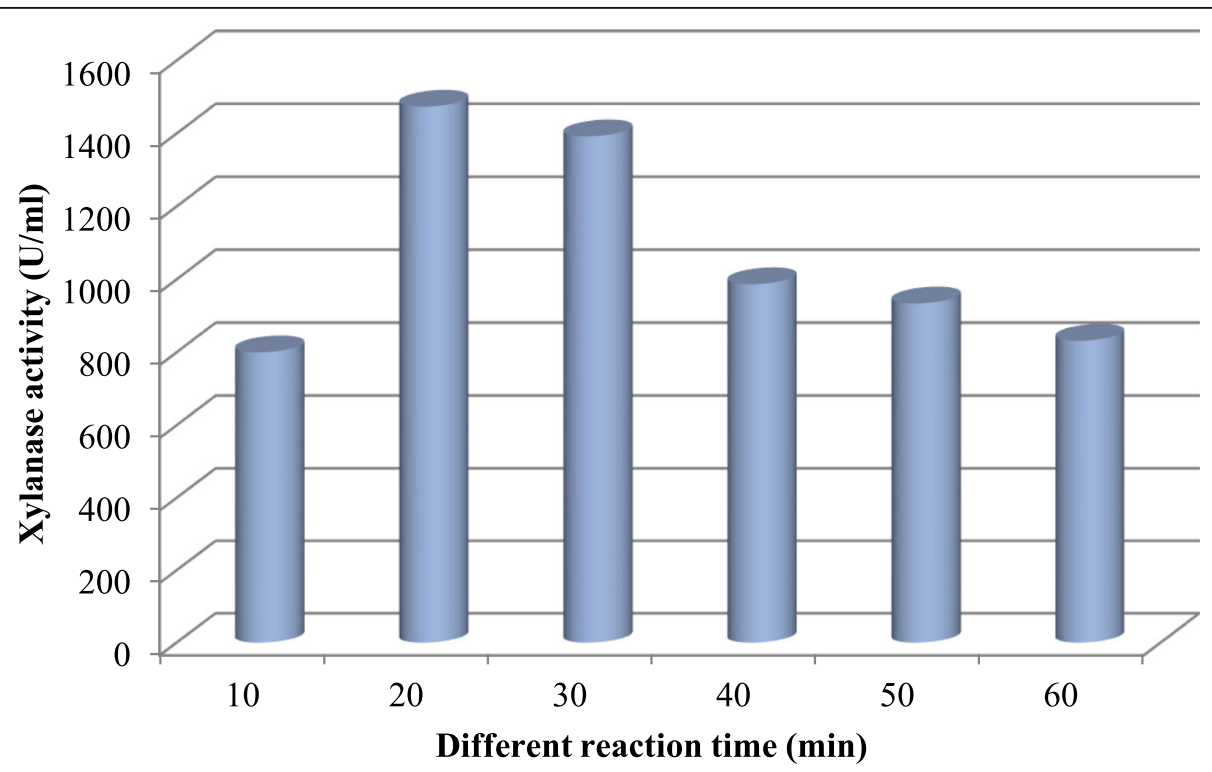

Fig. 6 Effect of different reaction time on crude xylanase activity 


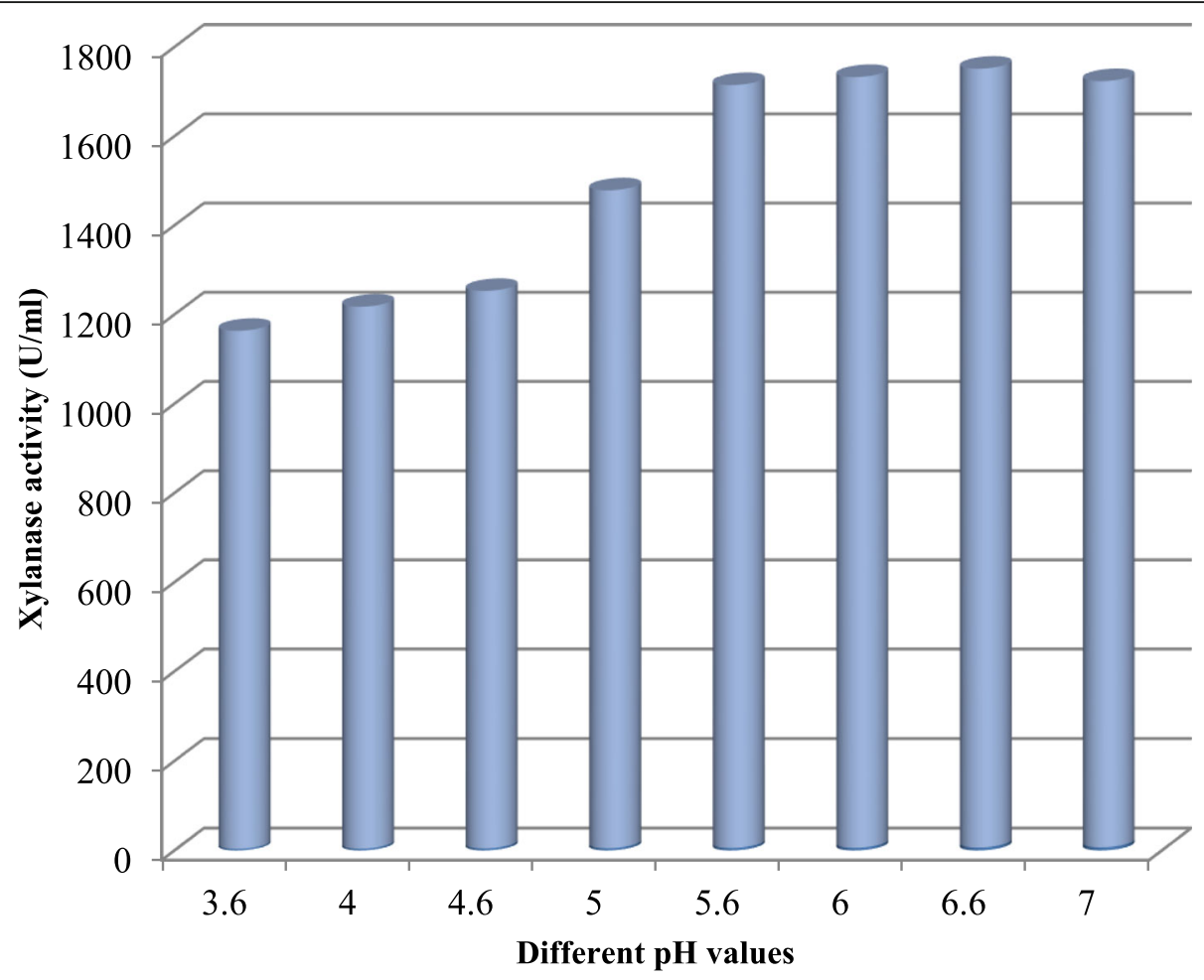

Fig. 7 Effect of different pH values on crude xylanase activity

\section{In vitro antifungal activity of crude xylanase (biocide)}

Effect of crude xylanase (biocide) on mycelia growth and zone of inhibition of some pathogenic fungi isolated from legume seed. Results showed that biocide showed higher antifungal activity than control in
(Table 2) highest inhibition against $R$. solani, $F$. solani, and M. phaseolina shown by the zone of inhibition 13.0, 13.0, and 7.0, respectively, as shown by the reduction in linear growth $78.8,73.3$, and 60.0 for all organisms.

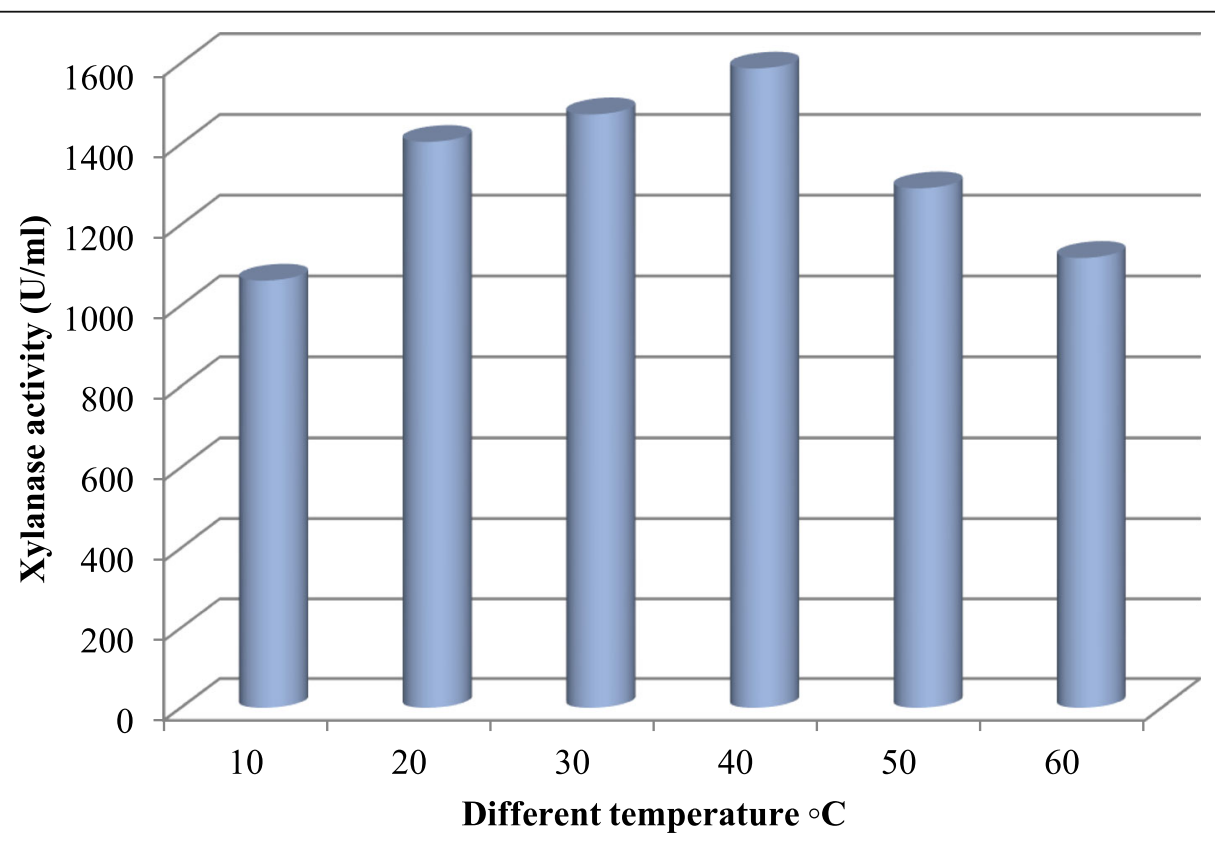

Fig. 8 Effect of different temperature ${ }^{\circ} \mathrm{C}$ on crude xylanase activity 


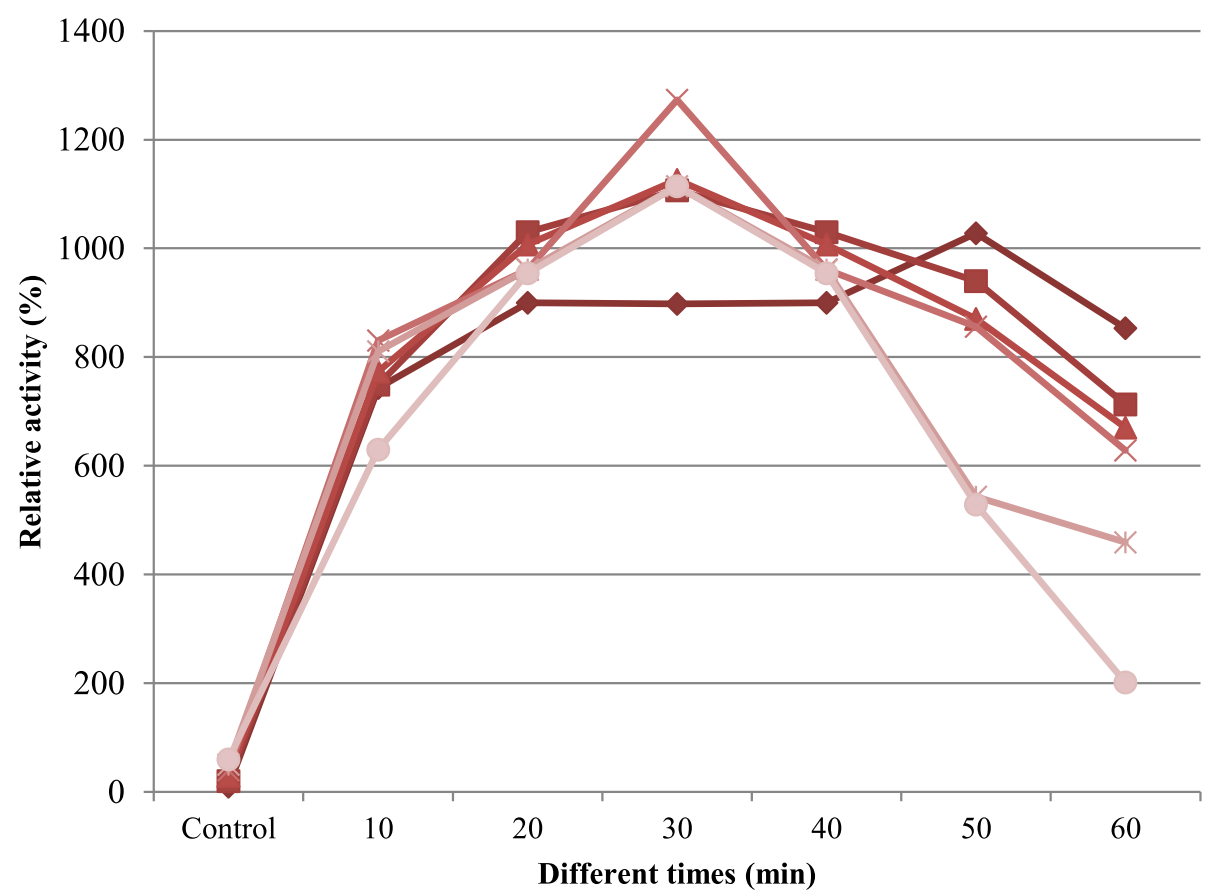

Fig. 9 Thermal stability of crude xylanase from C. globosum

\section{Greenhouse experiments}

The data in Table 3 show that based could highly significantly reduce disease incidence of beans which have been artificially infested with root rot pathogens, compared to untreated control treatments. Seed coating with biocide gave significant protection to emerge bean seeds against invasion of pathogenic fungi at the preemergence stage. Seed coating recorded more than 50\% protection compared with the untreated control. At the post-emergence stage, data also showed that treatment with biocide could reduce the percentage of root-rot incidence more than th2 untreated control (treatment with pathogens alone). Treatment with biocide caused reduction in the percentage of root-rot incidence recorded at
59.5\%, 59.2\%, and 42.2\% in soil infested with R. solani, F. solani, and $M$. phaseolina, respectively.

\section{Discussion}

Utilization of pomegranate peel $(\mathrm{Pp})$ produces maximum xylanase activity. This result was coincided with Shabeena et al. (2017) who found that production of xylanase by Aspergillus japonicas was most promising using wheat bran as carbon source; use of alternative agricultural residues as carbon sources reduces the cost of final products. Also, Betini et al. (2009) found that the use of agricultural wastes as carbon source reduces the cost of xylanase production by studying the effect of orange

Table 1 Frequency of seed borne fungi recorded from five different legume seeds

\begin{tabular}{|c|c|c|c|c|c|}
\hline \multirow[t]{3}{*}{ Fungal sp. } & \multicolumn{5}{|c|}{$\%$ Occurrence } \\
\hline & \multicolumn{5}{|c|}{ Seed/sample } \\
\hline & Chick pea & Faba bean & Lentil & Pea & White bean \\
\hline Alternaria alternate & - & - & - & 21.7 & - \\
\hline Aspergillus flavus & - & 9.1 & 21.4 & 4.3 & - \\
\hline Aspergillus niger & 13.3 & 22.7 & - & 17.4 & 8.0 \\
\hline Fusarium spp. & 33.3 & - & 35.7 & - & - \\
\hline Fusarium solani & - & 27.3 & - & 43.5 & 24.0 \\
\hline Macrophomina phaseolina & - & - & - & - & 32.0 \\
\hline Rhizoctonia solani & 40.0 & 27.3 & - & - & 36.0 \\
\hline Penicillium spp. & 13.3 & 13.6 & 26.0 & 13.0 & - \\
\hline
\end{tabular}


Table 2 In vitro antifungal activity of biocide from Pp on mycelial growth and zone of inhibition of some pathogenic fungi isolated from legume seeds

\begin{tabular}{llll}
\hline $\begin{array}{l}\text { Pathogenic } \\
\text { fungi }\end{array}$ & \multicolumn{2}{l}{ Biocide from pomegranate } & Zone of inhibition (mm) \\
\cline { 2 - 4 } & Linear growth $(\mathrm{mm})$ & Reduction (\%) & 4.0 \\
\hline A. alternate & 51.0 & 43.3 & 3.0 \\
A. solani & 50.0 & 44.4 & 13.0 \\
F. solani & 24.0 & 73.3 & 5.0 \\
F. oxysporum & 39.0 & 56.7 & 7.0 \\
M. phaseolina & 36.0 & 60.0 & 13.0 \\
R. solani & 19.0 & 78.8 & 0.0 \\
Control & 90.0 & - &
\end{tabular}

peel, orange pomace, lemon peel, lemon pomace, apple peel, banana peel, pear peel, hazelnut shell, and melon peel on the production of xylanase from Trichoderma harzianum 1073-D3, as well as Seyis and Aksoz (2005) who discovered that the addition of molasses as carbon source increases xylanase production followed by melon peel. Production of xylanse by Penicillium janthinellum uses different agricultural wastes (Oliveira et al. 2006), in addition to Dobrev et al. (2007) who use corn cob for xylanase production in shaking media inoculated with Aspergillus niger B03. Also, this results were similar to Venkatesh and Tallapragada (2009) and Nitin et al. (2017) where $A$. niger produces xylanase using wheat bran and pea peel as sole carbon source.

Comparison between different agricultural wastes on xylanase production by C. globosum, Darshna et al. (2017) found that $10 \mathrm{~g} / \mathrm{l}$ of $\mathrm{Pp}$ was most suitable for xylanase production from $A$. niger and Venkatesh and Tallapragada (2009) who illustrated that higher inoculum size for xylanase production from $A$. niger is using wheat bran as substrate produces higher xylanase activity. Also, Antoine et al. (2010) found that xylanase activity was maximum using disks $5 \mathrm{~mm}$ in diameter from Penicillium canescens incubated in fermentation medium containing soya oil cake crushed. Higher enzyme production at advanced inoculum is related to the rapid growth of the fungus which resulted higher deprivation of the substrates and increase availability of the nutrients (Pang et al. 2006).
Addition of molasses as illustrated by Carlos et al. (2014) increases xylanase production after 7-day incubation period while with Antoine et al. (2010) found that Penicillium canescens produce xylanase after 7 days of incubation. While these results were not coincided with Venkatesh and Tallapragada (2009) who discussed that production of xylanase from $A$. Niger was most promising after 6-day incubation period, and Su et al. (2011) found that maximum xylanase Thermomyces lanuginosus SKYKY-1 was after 3-day incubation period produce $38.7 \mathrm{~g} / \mathrm{l}$ from corncobs and $17.5 \mathrm{~g} / \mathrm{l}$ from soybean meal. The maximum production of xylanase for optimum fermentation depends on the organism, the nature of the substrate, additive nutrients, and many other fermentable conditions (Dekker 1983; Mishra et al. 1985).

The same results obtained by DOS Reis et al. (2015) who found that higher concentration of xylanase from Penicillium echinulatum S1M29 was obtained by the addition of calcium chloride in fermentation media. Addition of other salts illustrated by Maciel et al. (2009) who noticed that Aspergillus niger LPB 326 produced in fermentation media containing sugarcane bagasse in addition of the mineral salt solution. Also, Nayyar et al. (2017) discuss that production of xylanase from A. niger increases in presence of salts in fermentation media and Radhika and Monika (2014) who illustrate that Gordonia sp. increase xylanase production in presence of sodium chloride.

Table 3 Effect of bean seed application with biocide on pre- and post-emergence damping off caused by F. solani, M. phaseolina, and R. solani

\begin{tabular}{lllll}
\hline Treatments & Percentage (\%) pre-emergency & Percentage (\%) reduction & Percentage (\%) post-emergency & Percentage (\%) reduction \\
\hline F. solani & $28.0 \mathrm{a}$ & - & $33.3 \mathrm{a}$ & - \\
F. solani + Biocie & $12.0 \mathrm{~b}$ & 57.1 & $13.6 \mathrm{~b}$ & 59.2 \\
M. phaseolina & $32.0 \mathrm{a}$ & - & $41.2 \mathrm{a}$ & - \\
M. phaseolina + Biocide & $16.0 \mathrm{~b}$ & 50.0 & $23.8 \mathrm{~b}$ & 42.2 \\
R. solani & $32.0 \mathrm{a}$ & - & $35.3 \mathrm{a}$ & - \\
R. solani + Biocide & $16.0 \mathrm{~b}$ & 50.0 & $14.3 \mathrm{~b}$ & 59.5 \\
\hline
\end{tabular}

Figures with the same letter are not significantly different $(p=0.05)$ 
Simone et al. (2009) found that the maximum xylanase activity obtained from the culture filtrate of $A$. fumigatus and $A$. niveus was after $1 \mathrm{~h}$ of the beginning of the reaction. As well as Taneja et al. (2002) who used A. nidulans KK-99 to report that xylanase was active in after $1 \mathrm{~h}$ and retained almost $80 \%$ of its activity $60 \mathrm{~min}$ after the start of the reaction was most suitable for xylanase production from Aspergillus niger DFR-5 (Ajay and Farhath 2010).

This result of different $\mathrm{pH}$ values was not the same with Cai et al. (2004) who found that the optimum $\mathrm{pH}$ value of xylanase activity from the culture filtrate of Pleurotus ostreatus SYJ042 was 6.0. Simone et al. (2009) found that $\mathrm{pH}$ 5.0-5.5 increase xylanase activity from crude filtrates of A. fumigatus while optimum $\mathrm{pH}$ of $\mathrm{A}$. niveus was 4.5-5.0. Pill (2000) illustrated that xylanase activity from Penicillium sp. was at acid range.

This result of temperature was coincided with Ryan et al. (2003) who found that $40{ }^{\circ} \mathrm{C}$ was the optimum for xylanase production from Penicillium sp., while not coinciding with Hsin-Yu et al. (2007) who found that the optimum temperature for crude xylanase activity from Aspergillus carneus M34 was $60{ }^{\circ} \mathrm{C}$. As well as Adriana and Eleonora (2008) found that $50{ }^{\circ} \mathrm{C}$ was the optimum temperature for xylanase activity from $P$. sclerotiorum.

Thermal stability is an interesting enzymes property due to the great industrial importance as discussed by Eijsink et al. (2005) due to the stability of enzyme at different temperatures and times (Adriana and Eleonora 2008). Simone et al. (2009) xylanase enzymes from both A. fumigatus and $A$. niveus were stable at $60{ }^{\circ} \mathrm{C}$ for 30 min while after $1 \mathrm{~h}$ activity retained up to $85 \%$.

Khanzada et al. (2002) and Al-Abdalall (2008) found that seed borne pathogen presents externally, internally, or associated with the seed as contaminant may cause seed abortion, seed rot, seed necrosis, reduction, or elimination of germination capacity as well as seedling damage resulting in the development of disease at later stages of plant growth by systemic or local infection.

The antifungal activity of xylanase extract against some phytopathogenic fungi has been previously reported; the different pomegranate extracts on linear growth of different fungi; the highest antifungal activity was recorded in $A$. niger followed by P. citrinum and $R$. oryzae, respectively. Similarly, crude xylanase reduction linear growth of $A$. alternata, $F$. oxysporum, Phoma destructive, $R$. solani, and Sclerotium rolfsii with different degrees of activity against the tested fungi (Al-Askar 2012 ; Mangang and Chhetry 2012).

Greenhouse experiments obtained results are in agreement with those reported by Satish et al. (2007), the antifungal activity against seed borne pathogens of Aspergillus spp. as the result of application pomegranate peel extract. Also, pronounced decrease was found in citrus green mold disease $P$. digitatum as a result of application of pomegranate peel extract (Tayel et al. 2009). In another study, soil treatment with a pomegranate leaf extract before sowing effectively reduced damping off disease of French bean caused by Rhizoctonia solani, under greenhouse and field conditions. Xylanase is good biocontrol for green and blue mold of orange and lime fruit (El Shamy et al. 2016).

\section{Conclusion}

Different agricultural wastes were tested for xylanase production from them; pomegranate peel was most effective at concentration $40 \mathrm{~g} / \mathrm{l}$ using 2 disk $6 \mathrm{~mm}$ in diameter after 7-day incubation period in addition of calcium chloride increases xylanase activity. The crude xylanase activity was active after 20 min of starting of reaction at $6.6 \mathrm{pH}$ and $40{ }^{\circ} \mathrm{C}$ of the reaction mixture. Xylanse retained $85 \%$ of activity at $60{ }^{\circ} \mathrm{C}$.

Seeds of some legumes were examined for seed borne mycoflora by the agar plate method. The most common fungi were Fusarium solani, Rhizoctonia solani, and Macrophomina phaseolina.

Testing of crude xylanase as biocide was more effective in reduction of linear growth of some pathogenic fungi. Seed coating with biocide gave significant protection to emerge bean seeds against invasion of pathogenic fungi at the pre-emergence stage. Seed coating recorded more than $50 \%$ protection compared with the untreated control

\section{Acknowledgements \\ The authors acknowledge National Research Centre especially Chemistry of Natural and Microbial Products Department, Pharmaceutical and Drug Industries Research Division, Plant Pathology Department, and Agricultural and Biological Research Division for their helpful and encouragement.}

Availability of supporting data

Not applicable

Authors' contributions

All authors read and approved the final manuscript. Sherien Mohamed Mabrouk Atalla $(\mathrm{SH})$, selection of microorganism, enzymes assay, and optimization conditions. Nadia G. El-Gamal (NG), selection of microorganism and field experiment.

Authors' information

Not applicable

Funding

Not applicable

Ethics approval and consent to participate

Not applicable

Consent for publication

Not applicable

Competing interests

Not applicable

\section{Author details}

${ }^{1}$ Chemistry of Natural and Microbial Products Department, Pharmaceutical and Drug Industries Research Division, National Research Centre (NRC), Dokki, Giza 12622, Egypt. ${ }^{2}$ Plant Pathology Department, Agricultural and Biological Research Division, National Research Centre (NRC), Dokki, Giza 12622, Egypt. 
Received: 14 January 2020 Accepted: 9 June 2020

Published online: 23 June 2020

\section{References}

Adriana K, Eleonora CC (2008) Xylanase production by Penicillium sclerotiorum and its characterization. World Appl Sci J 4(2):277-283

Agarwal T, Malhotra A, Trivedi PC (2011) Fungi associated with chickpea,lentil and blackgram seeds of Rajasthan. Int J Pharm Bio Sci 2:478-483

Ajay P, Farhath K (2010) Production and extraction optimization of xylanase from Aspergillus niger DFR-5 through solid-state-fermentation. Bioresour Technol 101(19):7563-7569

Al-Abdalall AHA (2008) Pathological studies of fungi associated with pulse seed during storage in Dammam Province, Kingdom of Saudi Arabia. Mid East Russ J Plant Sci Biotech 2:71-77

Al-Askar AA (2012) In vitro antifungal activity of three Saudi plant extracts against some phytopathogenic fungi. J Plant Prot Res 52(4):458-462

Anonymous (1993) International rules for seed health testing. Seed Sci Technol: $211-288$

Antoine AA, Jacqueline D, Thonart P (2010) Xylanase production by Penicillium canescens on soya oil cake in solid-state fermentation. Appl Bioch Biotech 160(1):50-62

Atalla MMS, El Gamal GN, Awad MH, Ali FN (2019) Production of pectin lyase from agricultural wastesby isolated marine Penicillium expansum RSW_SEP1 as dye wool. Hely 5

Barnett HL, Hunter BB (1972) Illustrated genera of imperfect fungi, 3rd edn. Burgess Publishing Co, p 273

Betini JHA, Michelin M, Peixoto-Nogueira SC, Jorge JA, Terenzi HF, Polizeli MLTM (2009) Xylanases from Aspergillus niger, Aspergillus niveus and Aspergillus ochraceus produced under solid-state fermentation and their application in cellulose pulp bleaching. Bioprocess Biosyst Eng 32(6):819-824

Bobbarala V, Katikala PK, Naidu KC, Penumaj S (2009) Antifungal activity of selected plant extracts against phytopathogenic fungi Aspergillus niger f2723. Indian J Sci Technol 2:87-90

Cai Q, Yue X, Niu T, Ji C, Ma Q (2004) The screening of culture condition and properties of xylanase by white-rot fungus Pleurotus ostreatus. Process Biochem 39(11):1561-1566

Carlos RS, Luciana PV, Michele RS, Susan GK, Valesca W, Denise NX, Francieli SG, Michelle CTB, Vanete TS (2014) Enzymes production during value addition of agro-industrial wastes. Enz Value Add Was 1:1-108

Dahham SS, Ali MN, Tabassum H, Khan M (2010) Studies on antibacterial and antifungal activity of pomegranate (Punciagranatum L.).American-Eurasian. J Agric Environ Sci 9(3):273-281

Darshna K, Zainul A, Muhammad S, Sadaf J, Bilquees G, Muhammad A, Shakeel AK (2017) Plant cell wall hydrolyzing enzymes from indigosly isolated fungi grown on conventional and novel natural substrates. Pak J Bot 49(2):745-750

Dekker RFH (1983) Bioconversion of hemicelluloses: aspects of hemicellulase production by TrichodermareeseiQM9414 and enzymic scarification of hemicelluloses. Enzym Microb Technol 25:1127-1146

Diaz C, Hossain M, Bose ML, Mercea S, Mew TW (1998) Seed quality and effect on rice yield: findings from farmer participatory experiment in central Luzon, Philippines. J Crop Sci 23:111-119

Dobrev GT, Pishtiyski IG, Stanchev VS, Mircheva R (2007) Optimization of nutrient medium containing agricultural wastes for xylanase production by Aspergillus nigerB03 using optimal composite experimental design. Bioresour Technol 98(2671):2678

Dos Reis L, Ritter CET, Fontana RCM, Camassola M, Dillon AJP (2015) Statistical optimization of mineral salt and urea concentration for cellulose and xylanase production Penicillium echinulatum in submerged fermentation. Braz J Chem Eng 32(1)

Eijsink VGH, Gaseidnes TV, Borchet S, den Burg B (2005) Direct evolution of enzyme stability. Biomol Eng 22:21-30

El Shamy RA, EL Gamal GN, Atalla MMS (2016) Effect of different agricultural wastes on xylanase production by Saccharomyces cerevisiae and its application on citrus fruit. J Pure Appl Microbio 10(2):897-904

El-Mohamedy RSR, El-Gamal NG, El-Shamy AR, SMM A (2018) Biosynthesis of zinc nanoparticles and its effect on enzymes production by Bacillus subtilis and Pseudomonus flourescens using different agricultural wastes. Int J Agric 14(6):833-844

Hsin-Yu F, Shin MS, Meng CH, Tony JF (2007) Production, optimization growth conditions and properties of the xylanase from Aspergillus carneus M34. J Mol Catal B Enzym 49(1-4):36-42

ISTA (1976) International rules for seed testing (1976) Wageningen, Netherlands. Seed Sci Techol 4:3-49
Jae WL, Jun YP, Mi K, In G (2009) Purification and characterization of a thermostable xylanase from the brown rot fungus Laetiporus sulphureus. J Biosci Bioeng 107(1):33-37

Khalifa EZ (1987) Further studies on some soil borne fungi affecting soybean and their control. Ph.D.Thesis, Faculty Agric Menouif Univ, Egypt, p 148

Khanzada KA, Rajput MA, Shah GS, Lodhi AM, Mehboob F (2002) Effect of seed dressing fungicides for the control of seed borne mycoflora of wheat. Asian J Plant Sci 1(4):441-444

Maciel GM, Vandenberghe LPS, Fendrich RC, Bianca BED, Haminiuk CWI, Soccol CR (2009) Study of some parameters which affect xylanase production: strain selection, enzyme extraction optimization, and influence of drying conditions. Biotechol Bioproc E14:748-755

Mangang HC, Chhetry GKN (2012) Antifungal properties of certain plant extracts against Rhizoctonia solani causing root rot of French bean in organic soil of Manipur. Inter J Sci Res 2(5):1-4

Mishra C, Seeta R, Rao M (1985) Production of xylanolytic activities of Penicillium funiculosum. Enzyme Microb Techol 7(6):295-299

Monreal J, Reese ET (1969) The chitinase of Serratia marcescens. Can J Microbiol 15:689-696

Nayyar J, Faiza S, Afsheen A, Talat YM, Shah AU (2017) Utilization of agro waste pectin for the production of industrially important polygalacturonase. Hely 3:1-13

Neler J, Wassermann W, Kutner MH (1985) Regression, analysis of variance and experimental design, 2nd edn. Richard, D. Irwin Inc, Homewood

Nelson PE, Toussoun TA, Marasas WFO (1983) USA: Pennsylvania University . Press; pp.193.

Nitin KS, Vivek KT, Santosh KM (2017) The production of xylanase enzyme (E.C. Number $=3.2 .1 .8$ ) using solid substrate fermentation. Biotech Indian J Biotechnol 13(4):145

Ogbulie JN, Uwaezuoke JC, Ogiebor SI (2001) Introductory microbiology practical, 2nd edn. Concave Publishers, Nigeria, pp 95-113

Oliveira AL, Porto LFA, Tambourgi BL (2006) Production of xylanase and protease by Penicillium janthinellum CRC 87M_115 from different agricultural wastes. Bioresour Technol 97(6):862-867

Pang PK, Darah I, Poppe L, Szakacs G, Ibrahim CO (2006) Xylanase production by a local isolate, Trichoderma spp. FETL c3-2 via solid state fermentation using agricultural wastes as substrates. Malays J Microbiol 2(1):7-14

Pill II (2000) A laboratory guide to common Penicilliumspecies, 3th edn. Food Science Australia, North Ryde, p 187

Radhika K, Monika ES (2014) A novel thermo-alkaliphilic xylanase from Gordonia sp. is salt, solvent and surfactant tolerant. J Basic Microbiol 54(12):1342-1349

Ryan SE, Nolan K, Thompson R, Gubitz GM, Savage AV, Tuohy MG (2003) Purification and characterization of a new low molecular weight endoxylanase from Penicillium capsulatum. Enzym Microb Technol 33:775-785

Satish S, Mohanan DC, Raghavendra MP, Ravessha KA (2007) Antifungal activity of some plant extracts against important seed borne pathogens of Aspergillus sp. J Agr Tech 3(1):109-119

Seyis I, Aksoz N (2005) Xylanase production from Trichoderma harzianum 1073 D3with alternative carbon and nitrogen sources. Food Technol Biotechnol 43:37-40

Shabeena KS, Ravi M, Jayaraj YM (2017) Microbial production of xylanase using regional agro wastes. Int J Pharm Bio Sci 8(3):796-804

Simone CPN , Michele M, Jorge HAB, Joao A J, Hector FT, Maria de L, Teixeira MP (2009) Production of xylanase by Aspergilli using alternative carbon sources: application of the crude extract on cellulose pulp bioleaching. J Ind Microbiol Biotechnol 36:149-155.

Singh J, Tripathi NN (1999) Inhibition of storage fungi of black gram (Vigina mungo L.) by some essential oils. Flavour Frag J 14(1):1-4

Su Y, Zhang X, Hou Z, Zhu X, Guo X, Ling P (2011) Improvement of xylanase production by thermophilic fungus Thermomyces lanuginosus SDYKY-1 using response surface methodology. New Biotechnol 28(1):40-46

Taneja K, Gupta S, Kuhad RC (2002) Properties and application of a partially purified alkaline xylanase from an alkalophilic fungus Aspergillus nidulansKK99. Bioresour Technol 85:39-42

Tayel AA, Al-Baz AF, Salem MF, El-Hadary MH (2009) Potential application of pomegranate peel extracts for the control of citrus green mould. J Plant Dis Protect 116(6):252-256

Venkatesh K, Tallapragada P (2009) Optimization of growth condition for xylanase production by Aspergillus niger in solid state fermentation. Pol J Microbiol 58(2):125-130

\section{Publisher's Note}

Springer Nature remains neutral with regard to jurisdictional claims in published maps and institutional affiliations. 